\title{
S5ynthesis
}

International Scientific Conference of IT and Business-Related Research

\section{GEOHERITAGE SITES IN THE FUNCTION OF GEOTOURISM DEVELOPMENT IN THE REPUBLIC OF SERBIA}

\author{
OBJEKTI GEONASLEĐA U FUNKCIJI RAZVOJA \\ GEOTURIZMA U REPUBLICI SRBIJI \\ Tamara Višnić, Milica Began \\ Department of Geography, Tourism and Hotel Management, Faculty of Sciences, University of Novi Sad, \\ Trg Dositeja Obradovića 3, Novi Sad, Serbia
}

\begin{abstract}
:
The existence of various forms of mass tourism has led to development of special interest tourism destinations, including geotourism sites. Geological heritage sites are rare instances of outstanding geological, geomorphological, pedological and archaeological importance, used widely in recent years as a tool for the development of geotourism destinations. Over 600 geological sites have been identified in the Republic of Serbia, with only small portion of them being used for geotourism purposes. This paper identifies the most visited geodestinations by means of a questionnaire (Resava cave, Devil's town), as well as the level of tourist satisfaction with the destination, which could be described as very high. The directions for further development need to be set by identifying the existing condition of geoheritage sites in Serbia. The highest rated destinations need to expand their offer in order to attract a larger scale of visitors, while those not included in the list need to re-analyze and identify their limiting factors, and try to mitigate them.
\end{abstract}

\section{Key words:}

geoheritage, geotourism, Serbia, Resava cave, Devil' town.

\section{INTRODUCTION}

Geological diversity can bring a new level of understanding about the natural heritage of Serbia. Serbia disposes of extraordinary geoheritage with countless treasures and multiple opportunities for its inhabitants to learn more about their national heritage. Whilst this geoheritage is special, we have not always recognized, protected, managed or used it properly.

Geodiversity has been defined by Murray Gray as "the natural diversity of geological, geomorphological and soil features. It includes their assemblages, relationships, properties, interpretations and systems" (Gray 2004). Clearly, the key geodiversity phenomenon includes rocks, minerals, fossils, soils and landforms, as well as the processes affecting them. The examples of geodiversity that are of special conservation significance and that need to be conserved are recognised as geoheritage (Sharples 2001).

Another definition of geodiversity has been proposed by Semeniuk who defines geodiversity as: "the natural variety of geological, geomorphological, pedagogical, hydrological features of a given area from the purely static features, to the assemblage of products and their formative process" (Brocx 2008, p. 14).

\section{Apstrakt:}

Prisustvo različitih vidova masovnog turizma, uslovilo je pojavu turističkih destinacija od posebnog značaja, među kojima se nalazi i geoturizam. Objekti geonasleđa predstavljaju redak primerak od izuzetnog geološkog, geomorfološkog, pedološkog i arheološkog značaja koji se poslednjih godina u sve većem obimu koristi kao sredstvo za razvoj geoturističkih destinacija. Otkriveno je preko 600 objekata geonasleđa u Republici Srbiji, od kojih se samo mali broj koristi u geoturističke svrhe. U radu su primenom anketnog upitnika identifikovane najposećenije geodestinacije (Resavska pećina, Đavolja varoš), kao i stepen zadovoljstva geoturista destinacijom, koji bi se mogao oceniti kao izuzetno visok. Analizom postojećeg stanja geodestinacija u Srbiji pokušavaju se sagledati pravci daljeg razvoja. Ustanovljeno je da se od najbolje ocenjenih destinacija očekuje da svoju ponudu prošire u cilju privlačenja većeg obima posetilaca, dok je kod manje popularnih destinacija potrebno sprovesti ponovnu analizu, identifikovati nedostatke, a zatim ih otkloniti.

\section{Ključne reči:}

geonasleđe, geoturizam, Srbija, Resavska pećina, Đavolja varoš.

Geoheritage sites are the geological formations of exceptional scientific, educational and aesthetic values, which in addition to keeping the records of geological history of the planet, have tourism development potential.

Geoheritage is commonly irreplaceable and formal recognition should include adequate protection measures. It is suggested that geoheritage site access and protection, as part of the national geoheritage listing process, should be reviewed and improved by an expert working group to achieve enhanced and practical protection approaches for off-protected areas.

Geoheritage may have aesthetic values; economic values; functional values (such as soils and ecosystem functions) and research and education values (Gray 2004). Economic values could be interpreted through different forms of tourism, in particular geotoursm. Geotourism, as a term popularized by $\mathrm{Na}$ tional Geographic, refers to tourism that sustains or enhances the geographical characteristics of a place - its environment, culture, aesthetics, heritage and the wellbeing of its residents.

Geotourism incorporates the concept of sustainable tourism that destinations should remain unspoiled for future generations, and the principle of ecotourism that tourism revenue should promote conservation. 
As regards this, the paper aims to consider the conditions of geotourism, i.e., the value of geosites that could be or have already been exploited in terms of geotourism.

The aim of this paper is to determine the values that one geosite in the Republic of Serbia should possess in order to become attractive to consumers of geotourism on the local and international tourism market by taking into consideration the answers of geotourists. Also, this paper considers features of the most visited geodestinations in Serbia.

As the main tasks of this paper, we wanted to investigate if there are any differences between tourists regarding their attitudes about geotourism development in the Republic of Serbia.

\section{METHODOLOGY}

It is well-known that the most objective information about the quality of the destination is obtained on the basis of the research on consumers of these destinations, visitors of geological heritage sites. For the purpose of this work, the questionnaire aimed to gather the views of visitors in terms of satisfaction with the geological heritage sites.

The survey was conducted during the period from January to June 2014, on a sample of 204 respondents through online Google questionnaire.

Respondents under the age of 18 were not excluded, since the school trips are a large source of visitors to the geoheritage sites.

The survey consisted of three parts: the first part in which the subjects are required to complete the data on the socio-economic status, as shown in Table 1; the second part is related to the identification of the best geodestinations according to the respondents; while the last part included a 5-point Likert scale, where respondents could express their views or compliance based on the given arguments.

The results have been analyzed with different forms of statistical calculations to obtain quantitative indicators of tourist attitudes. The data were entered into the statistical program SPSS, version 20, where the application of Mann-Whitney's and Kruskal-Wallis' test gained insight into the real situation and satisfaction of certain geoturists with the geodestinations in the Republic of Serbia.

Non-parametric tests are used for the cases where independent variables are not metrical (Malhotra, 2005).

The logic behind the Mann-Whitney test is to rank the data for each condition, and then see how differently the two rank in total. If there is a systematic difference between the two conditions, then most of the high ranks will belong to one condition and most of the low ranks will belong to the other one (Graham, 2011).
The "Kruskal-Wallis one-way analysis of variance by ranks" is a method of comparing different samples to calculate whether there is a statistically significant difference between the ratings of those attributes. The method relies on the ranks of the scored values and the means of those ranks, rather than examining the means of the data (Goldstein, 2003).

We used these tests in order to prove the hypothesis which stands that there are no statistically significant differences between the respondents based on their preferable motives to travel or their level of education.

In Table 2 and 3, the rank means the number of subjects for each of the given groups.

The analysis of the questionnaire contributed greatly to identifying the best geotourism destination.

Upon identification, strengths and weaknesses of destinations themselves were taken into account using the SWOT analysis, which was of great importance when planning further development of a geodestination and making a decision on the objects of geological heritage that are worth investing funds in, in order to ensure further development.

\section{RESULTS AND DISCUSSION}

As shown in Table 1, the sample was predominantly singular in terms of gender structures. Out of the total number of respondents, $46.6 \%$ were men and $53.4 \%$ women. In terms of age, more than $90 \%$ of respondents deployed into three groups (up to 19 years, 20 to 40 and from 41 to 60 years). The lowest group of respondents (5.4\%) belong to the group "older than 61".

The level of education largely depends on the attitudes of respondents regarding various forms of tourist movements, primarily the motives to travel, as well as the expectations of the destination itself.

More than half of the total number of respondents, i.e., $56.4 \%$ have high school education, and $19.1 \%$ have a college degree. The respondents who have only completed primary school assume the third place with $18.6 \%$, and such a high percentage of participants with only primary school can be explained by the fact that a proportion of the respondents accounted for pupils who have visited certain geotourism destinations in field trips organized by some elementary or high school.

When it comes to the question of the basic motive to travel, a significant number of respondents (91.7\%) opted for cultural sites, while only $8.3 \%$ of respondents prefered visiting natural heritage sites.

This last question is extremely important in order to be able to continue with the analysis of respondents and their attitudes. By means of Man Whitney's test, we wanted to compare the attitudes of respondents who prefer taking trips to cultural sites

\begin{tabular}{|c|c|c|c|}
\hline Total number of respondents & $100 \%$ & Total number of respondents & $100 \%$ \\
\hline \multicolumn{2}{|l|}{ Sex } & \multicolumn{2}{|l|}{ Education } \\
\hline Male & 46.6 & Elementary School & 18.6 \\
\hline Female & 53.4 & High school & 56.4 \\
\hline \multicolumn{2}{|l|}{ Age } & College & 19.1 \\
\hline Up to 19 & 24.5 & Master/PhD Degree & 5.9 \\
\hline $20-40$ & 33.8 & Main Travel Motiv & \\
\hline $41-60$ & 36.3 & Natural Heritage & 8.3 \\
\hline Older than 61 & 5.4 & Cultural Heritage & 91.7 \\
\hline
\end{tabular}

Table 1. Socio-demographic profile of respondents 
with the respondents who prefer visiting natural sites, as shown in Table 2.

As can be concluded from the above-given table, the level of statistical significance (Sig.) is just in one item smaller than the limit value (0.05), which means that the attitudes of respondents from the two groups differ significantly in only one variable (Serbia has a great potential of natural tourism values).

In all other variables, there were no statistically significant differences between the attitudes of respondents, no matter if they prefer to take trips to cultural and natural attractions.

On the other hand, the level of education is one of the important criteria when choosing a tourist destination. In fact, education is largely determined by the attitudes regarding certain aspects of the geological heritage sites.
Table 3 presents the results of Kruskall - Wallis test that is applied as a non-parametric ANOVA test version, since the distribution of data by Kolmogorov - Smirnov test for independent variable "Education" did not show normal.

By means of the Kruskal Wallis test, we have shown that there are no statistically significant differences in the ranks of the respondents' answers depending on the level of their education. These statistically significant differences are noticeable in only 2 variables (Serbia will become one of the world's geotourism destinations in the near future and Geoheritage sites have a good promotion on foreign markets).

Geological heritage sites in Serbia represent exceptional wealth, which has a great tourist value or the potential for the geotourism development. Geosites are the base for further de-

\begin{tabular}{|c|c|c|c|c|c|}
\hline Item & Group & $\mathbf{N}$ & $\begin{array}{l}\text { Mean } \\
\text { Rank }\end{array}$ & $\begin{array}{c}\text { Mann } \\
\text { Whitney }\end{array}$ & Sig. \\
\hline \multirow{2}{*}{$\begin{array}{l}\text { The geotourism potential of the Republic of Serbia is extreme- } \\
\text { ly large }\end{array}$} & NAT & 17 & 150.5 & 773.5 & .000 \\
\hline & CUL & 187 & 98.14 & & \\
\hline \multirow{2}{*}{ Serbia aspires to become a developed geodestination } & NAT & 17 & 98.44 & 1520.5 & .744 \\
\hline & CUL & 187 & 102.87 & & \\
\hline \multirow{2}{*}{ Geosites in Serbia have exceptional touristic values } & NAT & 17 & 110.18 & 1459.0 & .497 \\
\hline & CUL & 187 & 101.8 & & \\
\hline \multirow{2}{*}{ Tourist presentation of geosites in Serbia is satisfying } & NAT & 17 & 132.12 & 1086.0 & .021 \\
\hline & CUL & 187 & 99.81 & & \\
\hline \multirow{2}{*}{ Ticket prices are affordable (if applied) } & NAT & 17 & 111.29 & 1440.0 & .493 \\
\hline & CUL & 187 & 101.70 & & \\
\hline \multirow{2}{*}{$\begin{array}{l}\text { Enough is being invested in the promotion of geotourism on } \\
\text { the domestic market }\end{array}$} & NAT & 17 & 82.65 & 1252.0 & .123 \\
\hline & CUL & 187 & 104.30 & & \\
\hline \multirow{2}{*}{$\begin{array}{l}\text { Enough is being invested in the promotion of geotourism on } \\
\text { the international market }\end{array}$} & NAT & 17 & 112.91 & 1412.5 & .319 \\
\hline & CUL & 187 & 101.55 & & \\
\hline \multirow{2}{*}{ The accessibility to the geosites is high } & NAT & 17 & 73.32 & 1093.5 & .027 \\
\hline & CUL & 187 & 105.15 & & \\
\hline \multirow{2}{*}{ Enough is being invested in the readjustment of the geosite } & NAT & 17 & 76.47 & 1147.0 & .049 \\
\hline & CUL & 187 & 104.87 & & \\
\hline
\end{tabular}

Table 2. Research Results based on Mann Whitney's Test

\begin{tabular}{|c|c|c|c|c|c|c|}
\hline Item & $\begin{array}{c}\text { El- } \\
\text { ementary } \\
\text { school } \\
(38)\end{array}$ & $\begin{array}{l}\text { High } \\
\text { school } \\
(115)\end{array}$ & $\begin{array}{c}\text { College } \\
(39)\end{array}$ & $\begin{array}{l}\text { MSc } \\
(12)\end{array}$ & $\begin{array}{c}\text { Kruskall } \\
\text { Wallis } \\
\text { Test }\end{array}$ & Sig. \\
\hline $\begin{array}{l}\text { The geotourism potential of the Republic of Serbia is } \\
\text { extremely large }\end{array}$ & 89.14 & 111.0 & 82.86 & 127.13 & 12.379 & .006 \\
\hline Serbia aspires to become a developed geodestination & 108.75 & 97.08 & 96.29 & 154.83 & 13.712 & .003 \\
\hline Geosites in Serbia have exceptional tourism values & 94.70 & 103.94 & 113.92 & 76.29 & 6.705 & .082 \\
\hline $\begin{array}{l}\text { Tourist presentation of geosites in Serbia is satisfy- } \\
\text { ing }\end{array}$ & 114.42 & 92.42 & 122.23 & 97.25 & 10.749 & .013 \\
\hline Ticket prices are affordable (if applied) & 92.67 & 106.37 & 101.29 & 100.46 & 1.803 & .614 \\
\hline $\begin{array}{l}\text { Enough is being invested in the promotion of geo- } \\
\text { tourism on the domestic market }\end{array}$ & 91.70 & 99.81 & 108.46 & 143.13 & 8.611 & .035 \\
\hline $\begin{array}{l}\text { Enough is being invested in the promotion of geo- } \\
\text { tourism on the international market }\end{array}$ & 99.30 & 87.34 & 128.97 & 171.83 & 55.237 & .000 \\
\hline The accessibility to the geosites is high & 114.84 & 97.96 & 99.45 & 116.83 & 3.405 & .333 \\
\hline $\begin{array}{l}\text { Enough is being invested in the readjustment of the } \\
\text { geosites }\end{array}$ & 118.93 & 94.50 & 111.33 & 98.38 & 6.458 & .091 \\
\hline
\end{tabular}

Table 3. The results of the Kruskall - Wallis' test 
velopment of geotourism can be developed, as without the existence of objects the development of geotourism will not be possible, since it is precisely facility-based, i.e., they constitute its essence. Furthermore, it was found that Serbia has a very large geological and geomorphological diversity, especially since the Mesozoic until the Holocene. Each geological period, as well as different paleoclimatic conditions, geological and geomorphological characteristics have left their mark on this particular area, so we distinguish a large number of geosites.

However, the richness that Serbia posseses, a long time remained known only to a narrow circle of several geographers who have studied these values. With the development of geotourism, there is a possibility that these values can be presented to a wider audience.

This paper presents the results in the form of the attitudes of those who have visited some geotourism destinations, where the geological sites whose scientific, educational, aesthetic values, was presented to the visitors.

The analysis of Mann Whitney's test has shown that one variable is statistically significant different according to the attitudes of visitors who prefer to visit cultural to natural attractions. The variables in which their views differ refer to the opinion of the value of geological heritage that Serbia has. This is understandable if we look at the fact that those who prefer visiting cultural heritage do not see the natural heritage as an important segment of the tourist offer. They mainly consider the cultural attractions of larger value, not only touristic but also educational and aesthetic values. By using Kruskall-Wallis test we wanted to check whether such a divergence in attitudes depends on the level of education.

Whether the cause of these results is insufficient knowledge of geography or geology and geomorphology, or lack of interest and preferences towards cultural values, we checked by the Kruskall-Wallis test where we compared the responses by level of education. As the hypothesis assumed, tourists will not differ in many variables. In terms of knowledge or familiarity with these processes, it is extremely important not to ignore the educational importance of sites, only because it is largely responsible for the position on the destination. If the tourists had realized the significance of what they had visited, their position on the object itself, but also on all other natural resources with similar or different contents would have changed. Those who are not sufficiently addressed, will not understand the true value, and therefore, will consider that Serbia does not possess exceptional natural resources. Also, if the educational importance is not adequately highlighted and adapted to different levels of education of visitors, they will also realize the true significance of objects.

Opinions are divided in terms of the level of education, and the preference for cultural and natural attractions.

The presentation of content on the destination was set aside as a variable where the respondents' attitudes differ significantly in terms of the level of education. Besides these variables, and attitudes regarding the possibility of Serbia becoming geotourist destination in the shortest possible period of time, as well as questions about promotions, which is associated with incomplete reassessment of the importance of geological heritage.

According to the results obtained by the research, a large proportion of respondents believe that the potential for the development of geotourism in Serbia is huge, but that promotion is at a very low level.

Geosites, according to the views of respondents, are difficult to access and investments in the renovation of these sites are not at a high level and significantly hinder the development of getourism and lead to the risk of degradation.
The second part of the survey contained questions related to the identification of geological heritage that respondents had the opportunity to visit, as well as their ranking. This way, it could not fully meet the requirements of objectivity and comprehensiveness of the fact that the tourists were limited to those destinations that have had the opportunity to visit. But, given that they decide which destinations will be visited, this method of identification is not entirely inappropriate to be included in the paper.

The respondents have listed the following geodestinations as the most visited ones: Resava cave, Devil's Town, Djerdap Gorge and Uvac Gorge (Table 4).

Resava cave is one of the oldest caves in the country located $20 \mathrm{~km}$ from Despotovac, in limestone hill called Babina Glava on the coast of the karst field Divljakovac. It is $4.5 \mathrm{~km}$ long, where 2,830 $\mathrm{m}$ have been explored, and a visit can be arranged for only about $800 \mathrm{~m}$. The interior of the cave comprises galleries, canals, poles and jewelery estimated to be 45 million years old. The process of equipping the cave lasted 10 years, which means that the cave was officially open to visitors on April, 22 1972 (Lazarević, 1991).

The natural phenomena "Djavolja Varoš" (Fig 1.) is situated in southeastern part of Serbia $30 \mathrm{~km}$ away from Kuršumlija. It features 202 exotic formations described as earth pyramids or "towers", as the locals refer to them. They are 2-15 m tall and 4-6 $\mathrm{m}$ wide at the base. These formations were created by strong erosion of the soil that was the scene of intense volcanic activity millions of years ago (Marković, 1973). Most of the pyramids have a cap or head - andesite block that protects them from destruction, while some lost this protection over time. Arrays are oriented transversely to the direction of gullies and troughs are separated between each other by corridors, steep ravines or shallow profiles (Maćejka \& Tanasković, 2008).

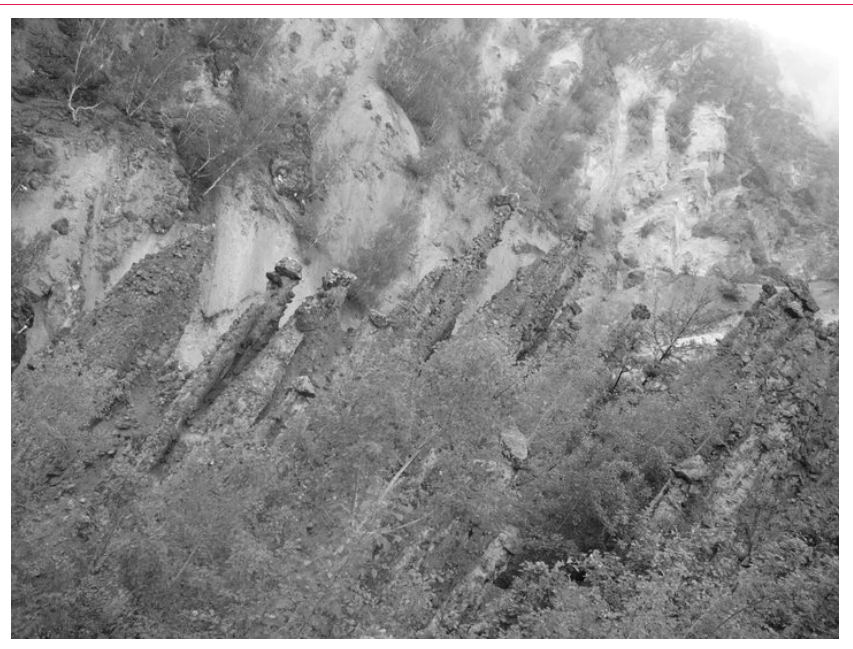

Fig 1. Djavolja Varoš (Devil's Town)

(photo: Višnić, T.)

The national Park Djerdap is situated in the northeastern part of Serbia, on the right side of the Danube and Djerdap Lake. At this point, the river separates the southern Carpathian Mountains from the northwestern foothills of the Balkan Mountains. The Romanian side of the gorge constitutes the Iron Gates natural park, whereas the Serbian part constitutes the Djerdap national park. The national park Djerdap was pronounced in 1974. The Djerdap gorge is $100 \mathrm{~km}$ long and is among the longest and most examined in Europe. It belongs to the type of gorge, respectively, antecedendent river valleys. Arranged downstream of the Danube are gorges and valleys, that alternate in 


\begin{tabular}{|c|c|c|c|c|c|}
\hline Name & $\begin{array}{c}\text { Type of natural } \\
\text { resource }\end{array}$ & $\begin{array}{l}\text { Accomodation } \\
\text { facilities }\end{array}$ & $\begin{array}{c}\text { Level of protec- } \\
\text { tion }\end{array}$ & Open for visits & Entrance fee \\
\hline Resavska cave & speleological & Despotovac & $\begin{array}{c}\text { Monument of } \\
\text { nature }\end{array}$ & $\begin{array}{c}\text { (whole year) april- } \\
\text { november }\end{array}$ & yes \\
\hline Devil's town & geomorfological & Kuršumlija & $\begin{array}{l}\text { Monument of } \\
\text { nature }\end{array}$ & $\begin{array}{l}\text { During the whole } \\
\text { year }\end{array}$ & yes \\
\hline Đerdap gorge & geomorfological & $\begin{array}{c}\text { Donji Milanovac, } \\
\text { Golubac }\end{array}$ & National park & $\begin{array}{l}\text { During the whole } \\
\text { year }\end{array}$ & no \\
\hline $\begin{array}{c}\text { Canyon of River } \\
\text { Uvac }\end{array}$ & geomorfological & $\begin{array}{c}\text { Sjenica, Nova } \\
\text { Varoš }\end{array}$ & Nature park & $\begin{array}{l}\text { During the whole } \\
\text { year }\end{array}$ & no \\
\hline
\end{tabular}

Table 4. Main data about the geoheritage sites

\begin{tabular}{|l|l|}
\hline \multicolumn{1}{|c|}{ Strenghts } & \multicolumn{1}{c|}{ Weaknesses } \\
\hline Exceptional scientific and educational value & Possibility of degradation \\
\hline Richness of geodiversity & Difficult site accessibility \\
\hline Aesthetic value & $\begin{array}{l}\text { Lack of tourism infrastructure that meets the requirements of } \\
\text { sustainable tourism development }\end{array}$ \\
\hline Low antopogenic influence & Unsuitable tourist presentation of the natural values \\
\hline The necessity of geoconservation & Threats \\
\hline The existence of complementary tourist values in the vicinity & Lack of experience in managing these types of destinations \\
\hline Adjustment of the tourism offer to different types of geoturists & $\begin{array}{l}\text { Week promotion of geosites on the domestic and foreign mar- } \\
\text { kets }\end{array}$ \\
\hline The organization of school trips, fieldwork and georutes & $\begin{array}{l}\text { Inadequate accommodation facilities (not in accordance with } \\
\text { the guidelines of sustainable development) }\end{array}$ \\
\hline
\end{tabular}

Table 5. SWOT analysis of the geoheritage sites in Republic of Serbia

the following order: Golubačka gorge, Ljupkovska valley, Gospodjin vir gorge, Donjomilanovačka valley, Veliki i Mali Kazan gorges, Oršavska valley and Sipska gorge (Stanković, 1975).

The canyon of River Uvac is a system of meanders the river builds on its course. For centuries, carving through the limestone rock, Uvac has made meanders and it now looks like a maze. Some of them have meanders and angle up to 270 degrees (Dragović, 2004).

All these sites of geological heritage can be described as extremely attractive. However, for the purpose of planning further geotourism development, as well as the financial investment in new projects, it is useful to know the type of resources at our disposal.

SWOT analysis is an analytical method used to define the critical factors that have the greatest impact on the positioning of a destination market. It is done through a matrix consisting of strenghts (Strenghts), weaknesses (Weaknesses), chances (Opportunities) and threats (Threats). This analysis can be used to identify and analyse the Strenghts and Weaknesses of a project, organization or institution, as well as the Opportunities and Threats revealed by the information gathered on the external environment. It can be used to develop a plan that takes into consideration many different internal and external factors, and maximizes the potential of the strenghts and opportunities while minimizing the potential of the weaknesses and threats (von Franz \& Shall, 2003).

In order to gain better understanding of the current position of the destination and define strategies to achieve the desired outcome and achieve business goals, this analysis could be used.

As shown in Table 5, the existence of exceptional scientific, educational and aesthetic values leads to the existence of the great potential for the development of geotourism on the geological sites. However, despite the fact that it is based on the principles of sustainable development, as well as every other form of tourism, geotourism can lead to the degradation of the geological heritage sites.

What is now referred to as a deficiency is certainly poor transport, and tourist infrastructure is inadequate to accept a greater number of tourists and fully satisfy their requirements.

In the future, it is necessary to protect geological heritage objects from further degradation, and find a way to ensure that the geodestination can evolve, with provided funds and professional staff.

\section{SUMMARY}

Geoheritage sites are the geological formations of exceptional scientific, educational and aesthetic value, which in addition to keeping the records of geological history of the planet, have the tourism development potential.

The purpose of the survey was to get an insight into the real state of geotourism in Serbia based on the attitudes of geoturists, to identify how consumers perceive geoheritage sites, whether they are considered truly valuable, as well as to identify the sites of geological heritage that have the greatest value for people.

The results show that the respondents have a generally positive attitude towards the potential of the Republic of Serbia for the development of geotourism, in other words, they are aware of the richness and value of geological heritage. Also, the attitudes of those who prefer visiting cultural sites do not statistically differ from those who prefer to travel in nature. 
Although the study was limited to the destinations visited by respondents, the paper presents the investigative findings that confirmed the hypothesis according to which the sites of geological heritage have a great tourism value, but it takes careful planning for further development with adequate long term funds, as indicated by the SWOT analysis.

Most frequently visited geoheritage sites are Resava cave and Devil's Town, as they are generally the only geological heritage equipped to meet the tourist demands. In the future, it is necessary to protect geological heritage through geoconservation, and adapt it to the needs of tourists, without the necessity for major changes that would force the geological heritage to lose some of its value.

\section{REFERENCES}

Brocx, M. (2008). Geoheritage: From Global Perspectives to Local Principles for Conservation and Planning. Perth: Western Australian Museum.

Dragović, R. (2004). Polimlje: priroda, turizam i održivi razvoj. Beograd: Srpsko geografsko društvo. (In Serbian).

Goldstein, Sh.D. (2003). Using Kruskal-Wallis to Improve Customer Satisfaction. Indianapolis: The Steele Group.

Graham, C. (2011). Hole Research Skills Mann-Whitney test handout version 1.0.
Gray, M. (2004). Geodiversity: Valuing and Conserving Abiotic Nature. Chichester: Wiley.

Lazarević, R. (1991). Rezultati mikroklimatskih merenja u Resavskoj pećini. Zaštita prirode, 43-44, 57-79. (In Serbian).

Maćejka, M. \& Tanasković, R. (2008). Opština Kuršumlija turistička monografija $i$ vodič, Kuršumlija: Turistička organizacija Kuršumlija. (In Serbian).

Malhotra, K.N. (2005). Cercetarea de marketing. Budapesta: Editura Akadémiai Kiadó.

Marković, J.Đ. (1973). Prirodne retkosti Jugoslavije. Posebna izdanja, 39, 77-87. Beograd: Srpsko Geografsko Društvo. (In Serbian).

Sharples, C. (2001). Indicators of the State of Geodiversity for Tasmanian State of the Environment Reporting. Unpublished Report to the State of the Environment Unit. Tasmania: Resource Planning and Development Commission.

Stanković, M.S. (1975). Turistička valorizacija veštačkih jezera SR Srbije. Beograd: Posebna izdanja Srpskog geografskog društva. (In Serbian).

von Franz, J., \& Shall, N. (2003). Practitioner's Guide: Strenghts, Weaknesses, Opportunities and Threats (SWOT). Bonn: Deutsche Gesellschaft für Technische Zusammenarbeit $(\mathrm{GmbH})$. 